\title{
Concept of Fatty liver and its management in Ayurveda
}

\author{
Available online at www.hjhs.co.in \\ REVIEW ARTICLE \\ Punam Behere (Saner) ${ }^{*, a}$, Nilesh Subhash Kulthe ${ }^{\text {b }}$ \\ ${ }^{a}$ M.D., Professor, Department of Kayachikitsa, SNKD Charitable Trusts Ayurved College, \\ Nallasopara, Palghar.. \\ ${ }^{\mathrm{b}} \mathrm{PhD}$ scholar, Deptartment of Kayachikitsa, Yashwant Ayurved College, Kodoli, Kolhapur. \\ DOI 10.22270/hjhs.v6i4.114
}

\begin{abstract}
Fatty liver disease is a most common liver disease affecting a wide range of population worldwide. It is caused due to excessive fat accumulation in liver cells resulting in inflammation in liver. There are various symptoms such as confusion, fatigue, weakness etc. Over-eating is the major lifestyle factor causing fatty liver disease. Alcoholic intake results in alcoholic fatty liver disease Ajirna (indigestion), Sthaulya (obesity) and Prameha (diabetes mellitus) which occurs due to the vitiation of Annavaha, Rasavaha and Medovaha Srotas acts as Nidanarthakara Rogas (diseases which cause another diseases) which may result in the manifestation of non-alcoholic fatty liver. According to Ayurvedic texts, Panchkarma (Virechana) and herbs like Bhumiamalaki and Guduchi etc. acts a hepatoprotective and improves the functioning of liver.
\end{abstract}

Keywords: Fatty liver disease, Sthaulya, Prameha, Roga, Virechana, Guduchi.

\section{Introduction}

Hepato biliary diseases are the serious ailments affecting population worldwide. Hepatobiliary disease includes a heterogeneous group of diseases of the liver and biliary system caused by viral, bacterial, and parasitic infections, alcohol consumption, poor nutrition, and metabolic disorders. The liver is a wellknown organ for Ayurveda. In Vedas, liver is mentioned by "Yakna" word. (1)

Yakritword id derived from Sanskrit word Yat i.e., conversion and Krit means to do. Yakrit is regarded as a main organ that executes all key metabolic tasks, and its disruption can result in a variety of Yakrit vikaras. Yakrit functions are altered when Pitta Prakopa nidanas are used frequently and excessively. Yakrit vikaras (liver disorders) are fully explained in various Samhitas.

Liver is the largest gland in the body, performing metabolism of all the nutritional substances. It is the commonest site for accumulation of fat because it plays central role in fat metabolism. (2) Fatty alteration might be moderate and reversible, or severe and cause irreversible cell harm and death, depending on the source and quantity of build-up. Fatty Liver is caused by disturbances in lipid metabolism in the liver caused by a variety of etiological causes. Fatty liver is a reversible disorder in which a big quantity of fat builds up in the liver cells due to steatosis. Fatty liver is a condition that occurs when the fat content of the liver surpasses $5 \%$ of the total weight of the liver or when more than $30 \%$ of the hepatic cells in a liver lobule have fat deposits. (3)

In Ayurveda, Yakrit dalludara refers to an increase in the size of the liver (Yakrit vridhi). Kaphaja Yakrit dalludara occurs when Kapha dosha increases, resulting in a rise in the size of the liver. The Meda inside the Yakrit is then increased, resulting in Medaja Yakrit dalludara. (41) NAFLD (non-alcoholic fatty liver disease), also known as hepatic steatosis and Kaphaja yakrit dalludara in Ayurveda, is 
characterised by fat deposition in the liver in the absence of heavy alcohol consumption. It is a worldwide public health problem caused by dietary hyper nutrition, which leads to obesity and type II diabetes, and is linked to smoking, hypertension, and dyslipidaemia. Nonalcoholic fatty liver disease is an umbrella term for a histological spectrum ranging from simple steatosis, defined as a concentration of hepatic triglycerides greater than five percent of liver weight. The aetiology of fatty liver is divided into two types as mentioned in figure 1. The first group includes circumstances in

\section{Conditions with excess fat}

- Diabetes mellitus

- Obesity

- Hyperlipidaemia

Figure 1. Etiology of fatty liver

\section{Etio-pathogenesis}

The Ranjaka pitta, which turns Apya Rasa Dhatu into Rakta Dhatu, is based in Yakrit. It is also associated to Raktavahi and Mamsavahi Dhamani and is the Mulasthana (place of origin) of Raktavahasrotas. Yakrit is a significant Koshthanga that is closely linked to the Rasa, Rakta, and Mamsa Dhatus and plays a significant part in the Dhatu Parinama. (6) The key etiological causes of fatty liver include a high-fat diet, junk food, soft drinks, sedentary lifestyle, metabolic which there is an excess of fat on the body, putting additional strain on the liver's ability to metabolise fat. The second group includes liver cell damage, in which fat cannot be digested owing to harm to the liver cells.

The prevalence of Non-alcoholic fatty liver disease is $9-40 \%$ in Asia. Recent studies from the Indian subcontinent recorded a prevalence of $9-32 \%$ in the general population4. Insulin resistance, poor glycaemic control, and altered lipid metabolism have all been proposed as contributing factors to the molecular pathogenesis of disease. (5)

\section{Liver cell damage}

- Alcoholic Liver Disease

- Starvation

- Protein calorie malnutrition

- Chronic illness (e.g. TB)

- Acute fatty liver in late pregnancy

- Hypoxia ( Anemia, cardiac failure)

- Hepatotoxins (Carbon tetrachloride, chloroform)

- Drug induced liver cell injury syndrome (obesity, diabetes mellitus, dyslipidemia), medicines (corticosteroids, tetracyclin), etc. Figure 1 illustrates the aetiology of fatty liver disease. The Dushti of Annavaha, Udakavaha, Rasavaha, Raktavaha, Medovaha, etc. is caused by a high-fat diet, soft beverages, and a sedentary lifestyle, according to Ayurvedic theory. Nidanarthakara Rogas are Ajirna (indigestion), Sthaulya (obesity), and Prameha (diabetes mellitus) that result 
from the vitiation of the Annavaha, Rasavaha, and Medovaha Srotas. (7)

Fatty liver disease like Sthaulya, is a Santarpanajanya Vyadhi (disease caused by overeating) with Nidana (aetiology) and Samprapti (pathogenesis). Agnivikruti (Vitiation of the digestive system) causes the creation of Apakva Anna Rasa (Improperly produced digestive end product), which causes the vitiation of Kaphadosha and uneven formation and deposit of Meda (fat tissue) in Yakrit. Fatty Liver is the medical term for this ailment. Srotorodha (channel obstruction) is caused by vitiated Kapha and Meda, which promotes Vata. Agnivikruti is caused by vitiated Vata, and the cycle repeats. Hepatocytes undergo inflammatory alterations when Pitta is implicated in the pathophysiology, and the illness develops to the next stage, NASH. When Vata enters the picture, fibrosis develops, and the condition may advance to its extremes.

Hepatocytes experience inflammatory alterations when Pitta is implicated in the pathophysiology, and the illness develops to the next stage. When Vata enters the picture, fibrosis develops, which can lead to cirrhosis, ascites, and hepatocellular carcinoma, as well as other metabolic problems. Vitiation of Samanavayu, Apanavayu, Pachakapitta, Ranjakapitta, Kledaka kapha, Rasa Rakta Medo dhatu, and Pureesha are major variables involved in the etiopathogenesis of fatty liver. (8) Srotas associated in the aetiology and expression of fatty liver are Annavaha, Udakavaha, Rasavaha, Raktavaha, Medovaha, and Pureeshavaha.

\section{Predisposing factors}

- Type 2 diabetes and prediabetes

- Obesity

- Middle aged or older (although children can also get it)

- High levels of fats in the blood, such as cholesterol and triglycerides

- High blood pressure
- Certain drugs, such as corticosteroids and some cancer drugs

- Certain metabolic disorders, including metabolic syndrome

- Rapid weight loss

\section{Clinical sign and symptoms}

Patients with fatty liver disease manifest with abdominal heaviness and distention, increased or reduced hunger, constipation or diarrhoea, lethargy, and burp in the early stages. This situation is certainly comparable to Ajirna. (9) The presentation in obese people is quite similar to that of Sthaulya. When fatty liver progresses to the next stage, which resembles to Amlapitta (Gastroeosophageal Reflex Disease), in which patients experience sour eructation, chest and abdominal burning, abdominal distention, tastelessness, and loose stools. Systemic characteristics suggestive of more significant liver illnesses such as Pandu (Anemia, Fatigue, Altered Sensorium) (10), Kamala (yellowish sclera, skin, and urine), and Raktapitta (haematemesis) will become increasingly visible as the condition develops to Fibrosis and Cirrhosis. Finally, it manifests as one of the Ashtamahagada's eight primary ailments, namely Udara (Ascites); Yakriddalyudara is more prominent

\section{Management}

Dietary restriction, physical exercise and weight reduction form the first line of treatment. There is need of alternative treatment modalities which are safe and cost-effective. Ayurveda has immense potential in the management of fatty liver disease. Things to keep in mind while treating fatty liver are Agnivikruti, vitiation of Kapha and Meda at the Mula Sthana of Raktavaha Srotasa, Srotorodha and vitiation of Vata. Agnideepana (stimulation of digestive fire), Rookshana (dryness therapy), Srotosodhana (removal of blockage of channels), pacification of Kapha, Meda and Vata should be the first 
line of treatment in the management of Fatty Liver. Here, the treatment principle adopted is almost similar to that of Sthaulya. (11) When the fatty liver reaches the next stage and the Dhatus get engaged, therapy should focus on the purification of Rasa and Rakta, as well as Yakritshothahara (relieves hepatic inflammation).
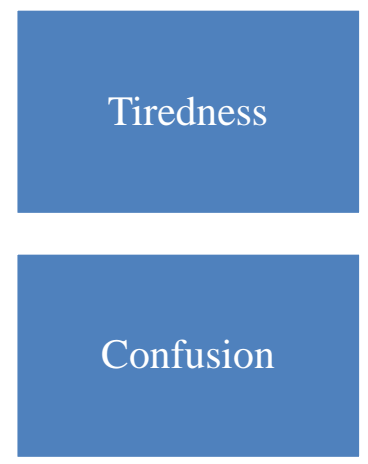
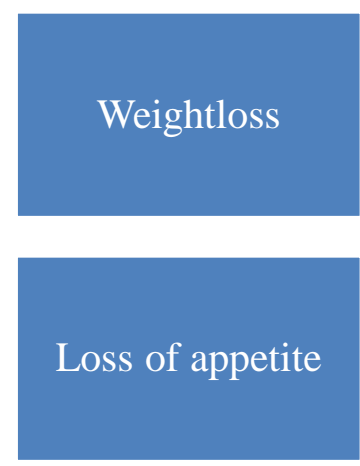
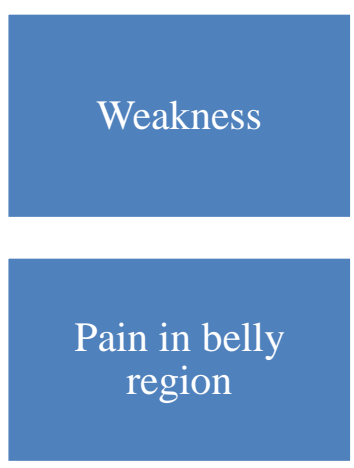

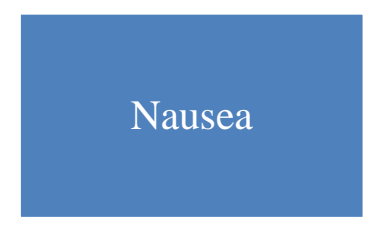

Dark patches on arms and neck

Figure 2. Some symptoms of Fatty liver disease

The careful use of the four treatment limbs, namely Samsodhana, Samshamana, Ahara, would aid in the reversal of fatty liver abnormalities and the avoidance of additional problems. In cases of liver problems, Virechana is the best Shodhana Karma. After undergoing Virechana therapy, patient experiences lightness in the body and improves the appetite. It is helpful in elimination excessive Pitta dosha alongwith Vata and Kapha dosha.Excessive Dosha buildup and Srotorodha are both indications. It has the properties of Agnideepana and Srotoshodhana. For this reason, a variety of Churna, Taila, Ghrita, and Avalehaconcoctions listed in classical writings and accessible in marketplaces are commonly employed. Patoladi, Hapushadi, etc. Patoladi, Hapushadi, Narayana, Avipatti, Erandataila, Trivrit Avaleha, Misraka sneha, and Haritakyadi ghrita are some of the Churnas that may be employed for this purpose. (12)

Vamana procedure is also helpful in reducing weight, total cholesterol levels and triglyceride levels. This therapy improves liver function by reducing the urea levels and serum creatinine levels.
Single herbs like Sharapunkha, Bhoomiamalaki, Katuki, Guduchi, Haritaki, Vasa, and Pippali can be utilised safely in Shamana chikitsa for the successful control. All of these medications shown hepato-protective property. Kashaya (Vasaguduchyadi, Phalatrikadi, Drakshadi, Patola Katurohinyadi), Arishta (Sudarshanaarishta, Rohitakarishta, Pippalyasava), Churna (Hinguvachadi, Vaiswanara), etc.

\section{Conclusion}

Alteration in the human-environment interaction is a key cause of all illnesses, including metabolic syndrome, which is mostly caused by poor nutrition and lifestyle choices. Fatty liver disease is an increasing condition that may progress to end stage liver disease. It has potential to progress to cirrhosis and liver failure. No established pharmacological treatment is available for fatty liver disease in modern medicine. Its treatment is still evolving, with no single drug clearly shown to be effective. Hence, there is a search for alternative treatment modalities in other systems of medicine, which is safe and cost-effective. As a result, nutrition and lifestyle have a significant role in the 
development, prevention, and treatment of fatty liver disease. The diet should be changed according to Acharya Charaka's "Eight Rules of Eating." Yoga and Pranayama may be incorporated into one's everyday practise to improve outcomes.

\section{Acknowledgements}

We would like to convey our sincere gratitude towards the HJHS Journal for publishing our article.

Financial Disclosure statement: The author received no specific funding for this work.

\section{Conflict of Interest}

The authors declare that there is no conflict of interest regarding the publication of this article.

\section{References}

1. Panda AK, Bhuyan GC, Rao MM. Ayurvedic Intervention for Hepatobiliary Disorders: Current Scenario and Future Prospect. J Tradit Med Clin Natur. 2017; 6: 210.

2. Angulo P, Non alcoholic fatty liver diseases. N. Engl. J Med. 2002; 346:1221-31.

3. Duseja A, Non alcoholic fatty liver diseases in India- a lot done, yet more required. Indian J Gastroenterol. 2010; 29:217-225.

4. Pt. Sastri Paradakara HS. Editor, Ashtanga Hridaya of Vagbhata. Reprint Edition, Nidanasthana, Ch. 8, Ver. 17 - 18. Varanasi: Chaukhambha Sanskrit Sansthan;, 2012.p. 497

5. Esler WP, Bence KK. Metabolic Targets in Nonalcoholic Fatty Liver Disease. Cell Mol Gastroenterol Hepatol. 2019;8(2):247-267.

6. Vaidya Trikamji J Acharya. Editor, Charaka Samhita of Charaka. Reprint Edition, Vimanasthana, Ch. 5, Ver. 11-15,21. Varanasi: Chaukhambha Orientalia; 2011.p. 251-252.

7. Chawla YK, Taneja S. API Textbook Of Medicine., 9th Edition, Vol. 1, Sec. 14, Ch. 11. Delhi: Jaypee Brothers Medical Publishers (P) Ltd; 2012.p. 886-887

8. Pt. Sastri Paradakara HS. Editor, Ashtanga Hridaya of Vagbhata. Reprint Edition. Sutrasthana, Ch. 14, Ver. 21. Varanasi: Chaukhambha Sanskrit Sansthan; 2012.p.226

9. Nisha MG. et al. The effect of parikara gutika in non-alcoholic fatty liver disease: A case study. Int. J. Res. Ayurveda Pharm. 2018;9(3):44-46.

10. J.D.Collier, Webster G. Davidson's Principles and Practise of Medicine. 21st Edition, Part 2,
Ch. 23. Churchill Livingstone Elsevier; 2010.p. 956-957

11. Vaidya Trikamji J Acharya. Editor, Susruta Samhita of Susruta, Sutrasthana. Ch. 14, Ver 4. Varanasi: Chaukhambha Sanskrit Sansthan; Reprint 2013.p.59

12. Vaidya Trikamji J Acharya. Charaka Samhita of Charaka. Reprint Edition. Vimanasthana, Ch. 1, Ver. 21. Varanasi: Chaukhambha Orientalia; 2011.p. 235 